\title{
CHLORIDE PENETRATION RESISTANCE OF CONCRETE SEALER AND COATING SYSTEMS
}

\author{
Khaled A. SOUDKI ${ }^{\mathrm{a}}$, Md. SAFIUDDIN ${ }^{\mathrm{b}}$, Paul JEFFS ${ }^{\mathrm{c}}$, \\ Gary MACDONALD ${ }^{\mathrm{d}}$, Marcos KROKER ${ }^{\mathrm{d}}$ \\ ${ }^{a}$ Department of Civil and Environmental Engineering, Faculty of Engineering, University of Waterloo, \\ 200 University Avenue West, Waterloo, Ontario, Canada N2L $3 G 1$ \\ ${ }^{b}$ School of Architectural Studies and Angelo del Zotto School of Construction Management, \\ George Brown College, 146 Kendal Avenue, Toronto, Ontario, Canada M5T 2T9 \\ ${ }^{c} P J$ Materials Consultant Limited, 11 Wagoners Trail, Guelph, Ontario, Canada N1G $3 M^{9}$ \\ ${ }^{d}$ Region of Waterloo, 150 Fredrick Street, Kitchener, Ontario, Canada N2G $4 J 3$
}

Received 02 Oct 2012; accepted 19 Nov 2012

\begin{abstract}
This study investigated the chloride penetration resistance of a silane-based sealer (SS1), an acrylic-based coating (AC1), and two cementitious coatings (CC1 and $\mathrm{CC} 2$ ) when applied on concrete surface. Concrete powder samples were collected from 15, 30 and $45 \mathrm{~mm}$ depths of sealer and coating treated concrete prism specimens, which were exposed to $\mathrm{H}_{2} \mathrm{O}$ and de-icing solutions of $\mathrm{NaCl}$, Geomelt $\mathrm{S} 30, \mathrm{MgCl}_{2}$ and $\mathrm{CaCl}_{2}$ for 100 freeze-thaw cycles followed by 25 wet-dry cycles. Chloride analysis was carried out to determine the total water-soluble chlorides of concrete. Test results revealed that the chloride penetration for exposure to the de-icing chemicals occurred at a depth of $15 \mathrm{~mm}$ from the concrete surface. The highest chloride penetration occurred for the non-treated concrete. The sealer 'SS1' exhibited good performance except with exposure to $\mathrm{NaCl}$ solution. Among the three different coating products, the acrylic-based coating 'ACl' was the best-performing coating, whereas the cementitious coating ' $\mathrm{CCl}$ ' had the worst performance. The amount of penetrated water-soluble chlorides was greater than the maximum recommended value of $0.025 \%$ (by concrete weight) at $15 \mathrm{~mm}$ depth for the sealer 'SS1' when exposed to $\mathrm{NaCl}$ de-icing solution, and for the coating ' $\mathrm{CCl}$ ' when exposed to $\mathrm{NaCl}, \mathrm{CaCl}_{2}$ and $\mathrm{MgCl}_{2}$ solutions.
\end{abstract}

Keywords: cementitious coating, chloride penetration, concrete, de-icing chemicals, penetrating sealer, water-soluble chlorides.

\section{Introduction}

De-icing or anti-icing chemicals are applied on bridge decks during winter for highway maintenance. They were first used on bridge decks in the U.S.A. during the 1940s (TRB 1991). In Canada, the use of de-icing or anti-icing chemicals on bridge decks began during the 1950s (JulioBetancourt 2009). These chemicals can be classified as chloride-based or non-chloride-based. Chloride-based deicing or anti-icing chemicals are generally used because of their low cost and relatively high effectiveness (TRB 2007). The most common chloride-based de-icing chemicals are $\mathrm{NaCl}$ and $\mathrm{CaCl}_{2}$, and more recently $\mathrm{MgCl}_{2}$ is also used as a de-icer. In addition, a formulated chloridebased de-icing/anti-icing liquid, commercially known as "Geomelt S30" is used in Southern Ontario (Soudki et al. 2011). It consists of $\mathrm{NaCl}$ brine and an organic salt accelerator derived from desugarized sugar beet juice.

Chloride-based de-icing/anti-icing chemicals are a common source of chloride ions that can penetrate a concrete surface. Many studies reported that the penetration of chlorides causes accelerated corrosion in reinforced concrete structures by destroying the protective passive film of the embedded steel reinforcement (Melchers, Li 2009; Pruckner, Gjørv 2004; Saremi, Mahallati 2002). Several research reports showed that $\mathrm{CaCl}_{2}$ and $\mathrm{MgCl}_{2}$ react with hydration products and form expansive oxychlorides (Julio-Betancourt 2009; Sutter et al. 2008), which result in cracking, thus causing increased permeability and a substantial loss of compressive strength. Also, Kozikowski et al. (2007) reported that $\mathrm{MgCl}_{2}$ forms magnesium silicate hydrate (M-S-H) and brucite $\left[\mathrm{Mg}(\mathrm{OH})_{2}\right]$ when it reacts with the hydration products of cement used in concrete. M-S-H decreases the strength of concrete at the expense of C-S-H, whereas $\mathrm{Mg}(\mathrm{OH})_{2}$ reduces the $\mathrm{pH}$ of the pore solution in the cement paste of concrete and thus accelerates reinforcement corrosion. The effect of chlorides becomes more detrimental in the case of cracked concrete due to increased permeability (Park et al. 2012). Moreover, chlorides not only accelerate reinforcement corrosion but also affect the scaling resistance of concrete. Bouteille et al.

Corresponding author: Md. Safiuddin

E-mail: msafiuddin@georgebrown.ca 
(2010) investigated the frost salt scaling resistance of concrete exposed to chloride solution with different concentrations; they found that the chloride concentration directly influences the amount of scaled mass from concrete surface. Though numerous studies were conducted on the chloride penetration into concrete, limited studies have been carried out on the chloride penetration resistance of concrete sealer and coating systems exposed to highly concentrated chloride solutions combined with freezing/thawing or wetting/drying cycles.

Sealers are typically classified as either penetrants or surface sealers that do not change the appearance of concrete to any significant degree. Coatings may be clear liquids, but typically are pigmented to improve the aesthetics of concrete. Safiuddin and Soudki (2011) surveyed the use of sealer and coating systems for the protection of concrete bridge structure; they concluded that sealers or coatings can protect the concrete from damages caused by the aggressive environmental and chemical exposures. The application of a sealer or coating on concrete surface can significantly impede the transport of chloride-laden water into concrete by making the surface layer hydrophobic or forming a physical barrier or combining both effects (Soudki et al. 2011).

Sealers and coatings have been applied as surface treatments onto concrete surface to reduce the penetration of chlorides into concrete for the protection of concrete bridge structures against corrosion (Ibrahim et al. 1999; Palle, Hopwood II 2006; Wenzlick 2007). The Kentucky Transportation Centre reported that a proper surface coating can protect reinforced concrete from corrosion by impeding the penetration of chloride ions (Palle, Hopwood II 2006). Al-Dulaijan et al. (2000), Almusallam et al. (2003), Ibrahim et al. (1999), Moon et al. (2007), and Oshiro and Tanigawa (1988) reported that surface coatings substantially slow down the chloride penetration into concrete and thus reduce the corrosion of steel reinforcement. On the contrary, penetrating sealers are not as efficient as surface coatings in improving the corrosion resistance of reinforced concrete (Ibrahim et al. 1999; Wenzlick 2007).

Kamaitis (2007a) analysed the mechanisms of degradation of polymer coatings caused by different aggressive actions and suggested predictive models for the deterioration over time that can be applied in designing the surface polymer coatings to preserve concrete structures. Moreover, Kamaitis (2007b) recommended the use of polymer protective coatings onto concrete surfaces where special protection against aggressive attack is necessary and demonstrated that polymer coatings can protect concrete from a variety of aggressive chemicals; his proposed models can be efficiently applied to assess the service life and performance of polymer protective coatings under different chemical exposure conditions. Kamaitis (2008) also took into account protective surface coating, concrete cover, and steel reinforcement in a whole to study the corrosion protection and service life of reinforced concrete structures. Recently, Yoon (2012) studied the effect of coating on chloride penetration through cracks in high-strength concrete with and without steel fibres; he concluded that coating can substantially reduce the chloride penetration into concrete. Nevertheless, most of the above-mentioned studies mainly focused the performance of polymer-based protective coatings. In addition, none of the aforementioned studies focused the effect of high concentration of different chloride-based de-icing/anti-icing chemicals on the performance of sealers or coatings. The combined effect of highly concentrated chloride solution, freezing/thawing, and wetting/drying was also not investigated in the above studies.

The present research study was undertaken to evaluate the chloride penetration resistance of four commercially available sealer/coating products using $\mathrm{H}_{2} \mathrm{O}$ and four de-icing chemicals $\left(\mathrm{NaCl}, \mathrm{CaCl}_{2}, \mathrm{MgCl}_{2}\right.$, and Geomelt S30). The chloride penetration resistance of the sealer and coating products was evaluated by quantifying the extent of chloride ingress into concrete. The sealer and coating treated concrete specimens were exposed to different highly concentrated chloride solutions along with freezing/thawing cycles, followed by wetting/drying condition. The chloride penetration at various concrete depths was obtained with respect to watersoluble chlorides, since they are more likely to contribute to corrosion of steel reinforcement (Dhir et al. 1990).

\section{Materials and methods}

The chloride analysis was carried out for control (nontreated) and surface-treated concrete prisms exposed to different de-icing chemicals. The types of surface treatment are shown in Table 1. The silane-based sealer (SS1) was used as a penetrating sealer, whereas the acrylicbased coating (AC1) and the two cementitious coatings (CC1 and $\mathrm{CC} 2)$ were used as surface coatings. The selected sealer and coating materials were applied on concrete

Table 1. Different surface treatments

\begin{tabular}{lr}
\hline Designation & Type of surface treatment \\
\hline $\mathrm{SS} 1$ & A silane-based penetrating sealer including corrosion inhibitor \\
\hline $\mathrm{AC} 1$ & A pigmented acrylic-based coating \\
\hline $\mathrm{CC} 1$ & A highly flexible, fibre-reinforced, two-component cementitious coating \\
\hline $\mathrm{CC} 2$ & A flexible, polymer-modified, two-component cementitious coating \\
\hline
\end{tabular}


prisms $(225 \times 225 \times 100 \mathrm{~mm})$ whose surface was prepared by abrasive blasting.

The concrete surface of the prism specimens was blasted using a stream of compressed air and abrasive material at a pressure of 95 psi. After abrasive blasting, the specimens were washed with water to remove the fine dust and loose materials. The profiles achieved after abrasive blasting replicated the degree of roughness for surface profile CSP 3 (Concrete Surface Profile 3), as specified by ICRI (1997). The abrasive blasting provided the required surface roughness for good adhesion of the coatings and opened the surface pores for penetration of the penetrating sealer. The sealer and coating materials were applied on the prepared concrete surface in accordance with the manufacturers' specifications. Before application, depending on the manufacturer's instructions for use, the blasted concrete surfaces were either dried or dampened/wetted.

The control (non-treated) and surface-treated concrete prisms were ponded with normal tap water and four de-icing chemicals with a ponding depth of approximately $6 \mathrm{~mm}$. Dikes were made on the non-treated and treated concrete surface using plexiglass bars to hold the water and solutions of de-icing chemicals during ponding. The de-icing chemical solutions were prepared based on the concentrations and formulations shown in Table 2. To formulate the solutions of different de-icing chemicals, the concentration of Geomelt S30, a commercially available de-icing solution in Southern Ontario, was used as a basis. The molal ion concentration of Geomelt S30, which had $16.3 \%$ active $\mathrm{NaCl}$, was 6.67. For comparison purposes, the other three de-icing solutions $\left(\mathrm{NaCl}, \mathrm{CaCl}_{2}\right.$, and $\left.\mathrm{MgCl}_{2}\right)$ were prepared to have the same molal ion concentration of Geomelt S30. The molal ion concentration was used, as it is based on the weight of solid salts and independent of temperature.

The ponding on the non-treated and surface-treated concrete prisms was carried out with 100 freeze-thaw cycles $\left(1\right.$ cycle: 16 hours freezing to $-20{ }^{\circ} \mathrm{C}$ and 8 hours thawing to $+20{ }^{\circ} \mathrm{C}$ ) followed by 25 wet-dry cycles
( 1 cycle: 4 days wetting at $23 \pm 2{ }^{\circ} \mathrm{C}$ and 3 days drying at $38 \pm 5^{\circ} \mathrm{C}$ ). The equivalent ponding period was significantly greater than the minimum ponding period of 90 days, as specified in AASHTO T 259-02 (2006) and ASTM C 1543-10a (2010).

Concrete powder samples were collected from the prism specimens by drilling at three different depths $(15$, 30 , and $45 \mathrm{~mm}$ ) following the environmental (freezethaw and wet-dry) exposures with de-icing chemicals. Seventy five powder samples were obtained from 25 concrete prisms, including 3 control samples. In addition, 6 powder samples were collected from 2 reference concrete prisms (not subjected to any environmental exposure) to determine the baseline chloride content of original concrete. From each prism, three powder samples were collected from the three selected depths. The weight of each drilled concrete powder sample was 10 to $15 \mathrm{~g}$, as needed for the chloride analysis. The details of the concrete powder samples are given in Table 3. The drilling operation and collection of concrete powder samples are shown in Figure 1. The drilling operation was carried out through the sides of the concrete prism specimens using a rotary-impact-type drill machine and maintaining the drilling direction parallel to the ponded surface. This process helped collecting of a test sample solely from the selected depth without contamination with concrete powder from the surface or other depths. Long small-diameter carbide tipped drill bits (length: $305 \mathrm{~mm}$, diameter: $8 \mathrm{~mm}$ ) were used in the drilling operation. While collecting the dust sample from each hole, care was taken to avoid contamination due to contact with hands and inclusion of foreign materials. It should be mentioned that the concrete powder from the first $25 \mathrm{~mm}$ of drilling depth was discarded, since that concrete segment was outside the ponding area and hence was not directly exposed to water or de-icing chemicals.

The water-soluble chloride content of the collected concrete powder samples was determined according to the RCTW (Rapid Chloride Test, Water-Soluble) method by using a commercially available test kit (RCTW

Table 2. Different chemical solutions

\begin{tabular}{|c|c|c|c|}
\hline \multirow{2}{*}{$\begin{array}{l}\text { Type of } \\
\text { solution }\end{array}$} & \multicolumn{3}{|c|}{ Concentration } \\
\hline & Molal ion-based & Weight-based & Formulation \\
\hline $\mathrm{H}_{2} \mathrm{O}$ & - & - & $100 \%$ tap water \\
\hline $\mathrm{NaCl}$ & 6.67 & $16.3 \%$ & $\begin{array}{c}1000 \mathrm{~g} \text { tap water, } \\
194.8 \mathrm{~g} \mathrm{NaCl}(100 \% \text { solids })\end{array}$ \\
\hline Geomelt S30 & 6.67 & $16.3 \% \mathrm{NaCl}$ & $\begin{array}{c}70 \% \text { salt brine } \\
\text { (23.3\% NaCl plus } 76.7 \% \text { water), } \\
30 \% \text { Geomelt } 55 \text { concentrate } \\
\text { (de-sugarized beet juice) }\end{array}$ \\
\hline $\mathrm{CaCl}_{2}$ & 6.67 & $19.8 \%$ & $\begin{array}{c}1000 \mathrm{~g} \text { tap water, } \\
303.8 \mathrm{~g} \mathrm{CaCl}_{2} \text { (85\% solids) }\end{array}$ \\
\hline $\mathrm{MgCl}_{2}$ & 6.67 & $17.5 \%$ & $\begin{array}{c}1000 \mathrm{~g} \text { tap water, } \\
591.6 \mathrm{~g} \mathrm{MgCl}_{2}(47 \% \text { solids })\end{array}$ \\
\hline
\end{tabular}


Table 3. Test samples for chloride analysis

\begin{tabular}{lcccr}
\hline & \multicolumn{2}{c}{ Number of concrete prism specimens } & \multicolumn{2}{c}{ Sampling depth } \\
\cline { 2 - 4 } Type of exposure & $\begin{array}{c}\text { For non-treated } \\
\text { (control, no sealer/coating) }\end{array}$ & $\begin{array}{c}\text { For treated } \\
(1 \text { sealer and } \\
3 \text { coatings })\end{array}$ & $\begin{array}{c}\text { Number of powdered } \\
\text { samples }\end{array}$ \\
\hline None & 2 & - & $15,30,45$ & 6 \\
\hline $\mathrm{H}_{2} \mathrm{O}$ & 1 & 4 & $15,30,45$ & 15 \\
\hline $\mathrm{NaCl}$ & 1 & 4 & $15,30,45$ & 15 \\
\hline $\mathrm{Geomelt} \mathrm{S30}_{\mathrm{CaCl}}$ & 1 & 4 & $15,30,45$ & 15 \\
\hline $\mathrm{MgCl}_{2}$ & 1 & 4 & $15,30,45$ & 15 \\
\hline
\end{tabular}

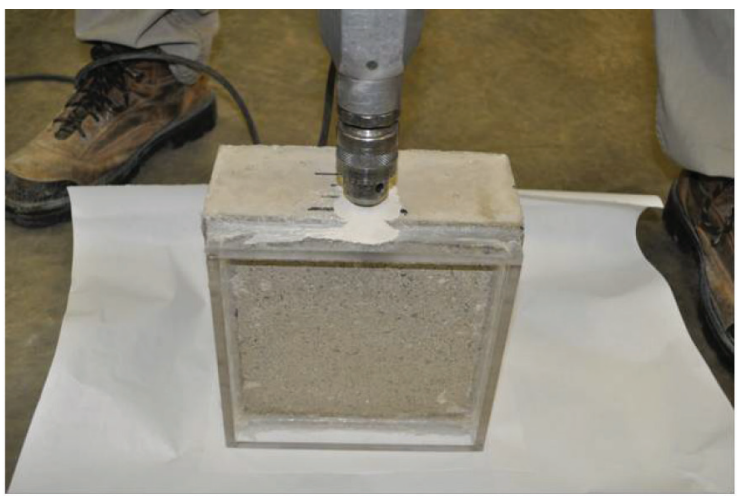

Drilling into concrete prism

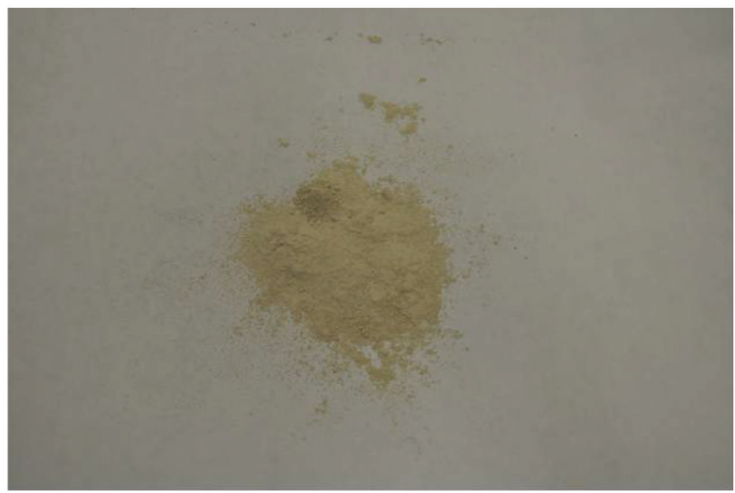

Extracted concrete powder sample

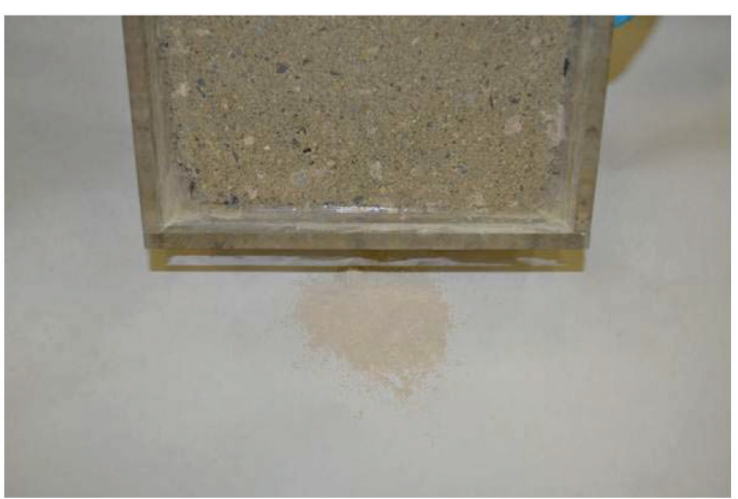

Extraction of concrete powder

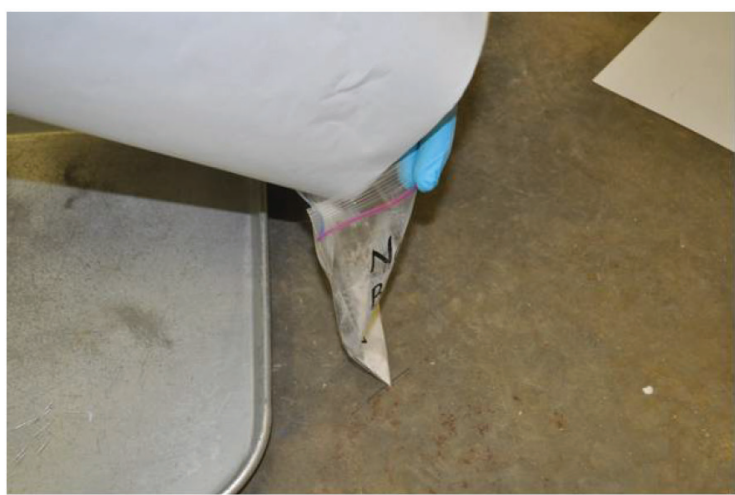

Transfer of concrete powder to plastic bag

Fig. 1. Drilling operation and collection of concrete powder samples

2002). In this test, a 1.5 -g concrete powder sample was first mixed with a 9-ml extraction liquid and shaken vigorously for $5 \mathrm{~min}$. Then the mixture of the powder sample and extraction liquid was poured into a filter paper cone for filtering into a vial containing a $1-\mathrm{ml}$ buffer. The filtered solution and buffer was also shaken for $1 \mathrm{~min}$ to obtain the final solution for chloride analysis. The calibrated chloride ion sensing electrode was submerged into the vial containing the chloride solution. The potential ( $\mathrm{mV}$ reading) was recorded from the high impedance electrometer. Later the $\mathrm{mV}$ reading was transformed into the water-soluble chloride content of concrete by means of the calibration chart $\left(\% \mathrm{Cl}^{-}\right.$by concrete weight vs. potential, $\mathrm{mV}$ ) as shown in Figure 2. The different steps of the RCTW test are shown in Figure 3.

\section{Test results and discussion}

The baseline chloride content for the test specimens was determined as the average water-soluble chloride content of powder samples obtained from the 15, 30 and $45 \mathrm{~mm}$ depths of two concrete prisms that were not ponded with water or any de-icing chemical (Table 4). 


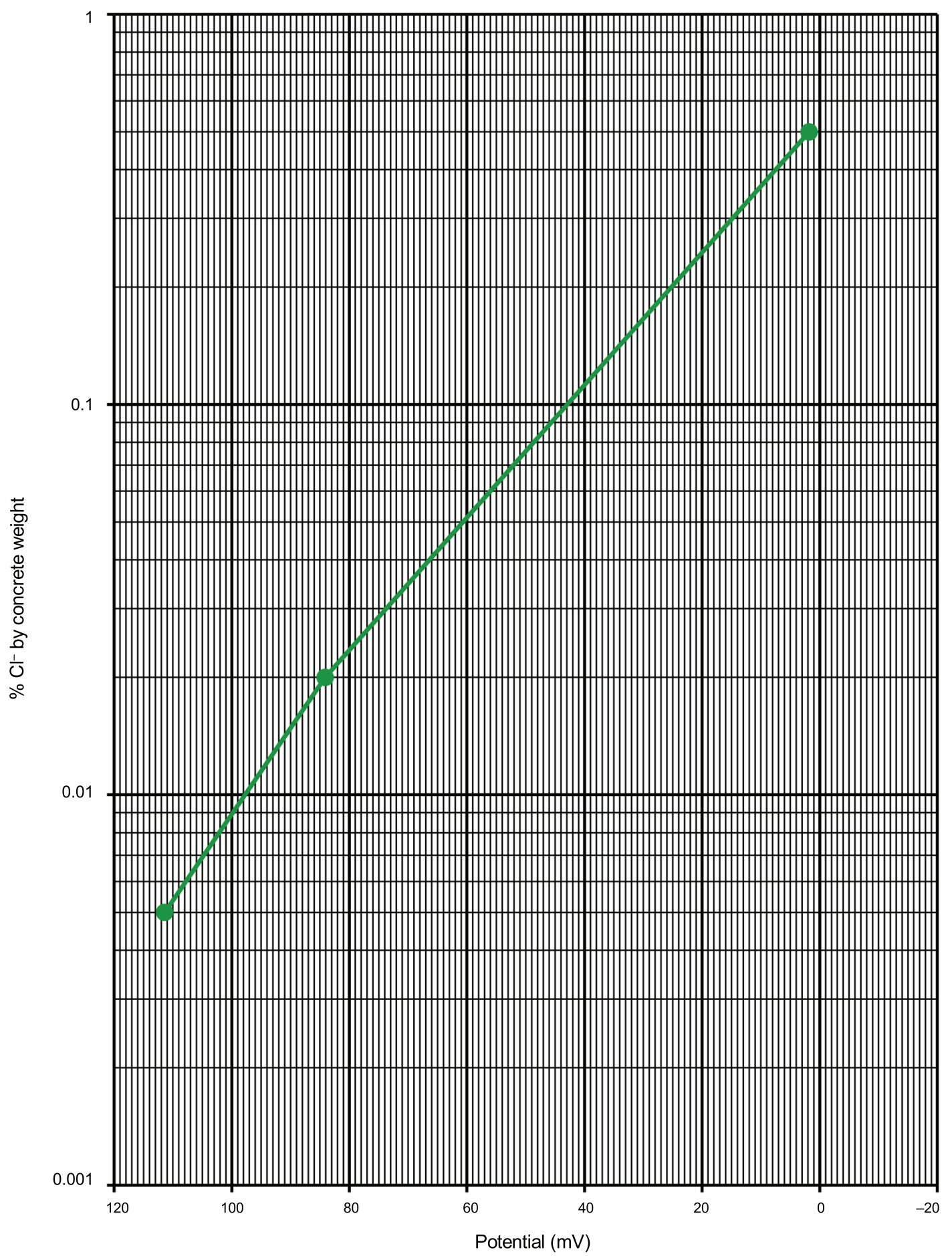

Fig. 2. Calibration chart

The measured total water-soluble chloride contents of non-treated and treated concretes exposed to different chemicals are given in Table 5) The total water-soluble chloride content includes the penetrated chlorides and the baseline chlorides (chloride content of original concrete). The amount of penetrated water-soluble chlorides was calculated by subtracting the baseline chloride content from the total water-soluble chlorides. When the re- sult was negative, it was taken as zero. Table 6 presents the penetrated water-soluble chlorides due to exposure to water and different de-icing chemicals. The chloride results in Table 6 revealed that the penetration of chlorides into concrete prisms occurred at a depth of $15 \mathrm{~mm}$. No penetration of chlorides occurred at the depths of 30 and $45 \mathrm{~mm}$. The detailed discussion of the results is given below. 


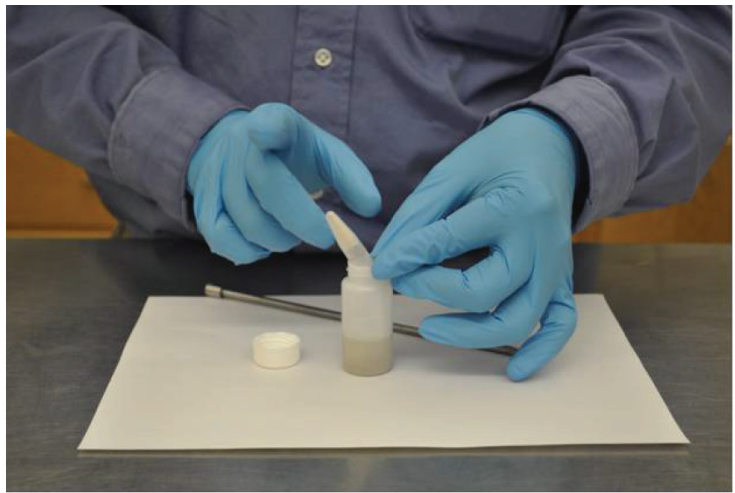

Mixing of concrete powder sample with extraction liquid

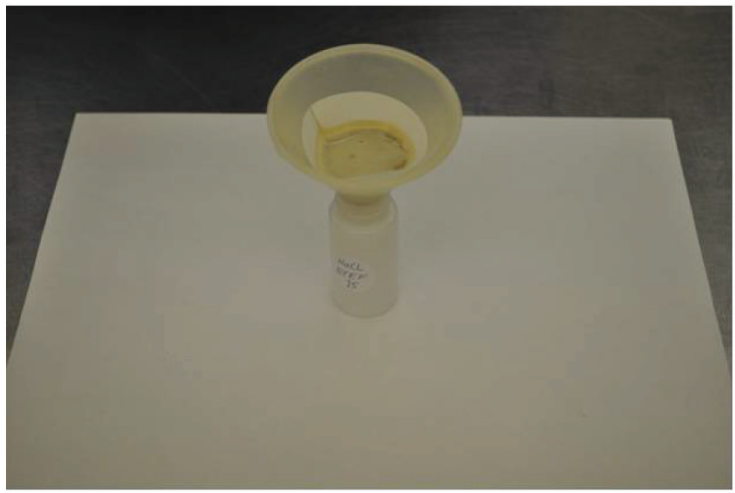

Filtering of mixture of concrete powder sample and extraction liquid
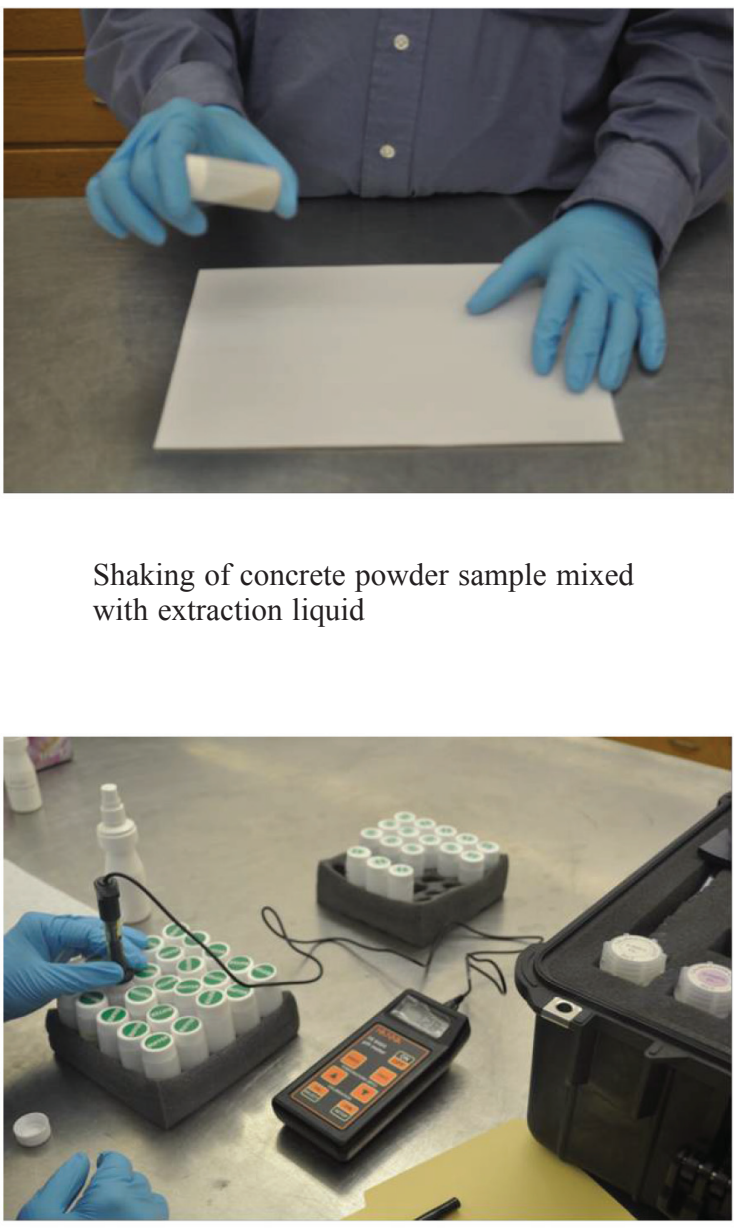

Shaking of concrete powder sample mixed with extraction liquid

Testing of total water-soluble chloride content of concrete by RCTW method

Fig. 3. Determination of water-soluble chloride content of concrete

Table 4. Water-soluble chloride content of original concrete

\begin{tabular}{|c|c|c|c|c|c|c|}
\hline \multirow{3}{*}{ Specimen } & \multicolumn{6}{|c|}{ Depth of sampling } \\
\hline & \multicolumn{2}{|c|}{$15 \mathrm{~mm}$} & \multicolumn{2}{|c|}{$30 \mathrm{~mm}$} & \multicolumn{2}{|c|}{$45 \mathrm{~mm}$} \\
\hline & $\begin{array}{l}\text { Potential } \\
(\mathrm{mV})\end{array}$ & $\begin{array}{c}\text { Chloride } \\
\left(\% \mathrm{C}^{1}\right)\end{array}$ & $\begin{array}{l}\text { Potential } \\
(\mathrm{mV})\end{array}$ & $\begin{array}{c}\text { Chloride } \\
(\% \mathrm{C})\end{array}$ & $\begin{array}{l}\text { Potential } \\
(\mathrm{mV})\end{array}$ & $\begin{array}{c}\text { Chloride } \\
\text { (\% C) }\end{array}$ \\
\hline S1 & 64.9 & 0.041 & 67.5 & 0.038 & 64.5 & 0.041 \\
\hline S2 & 68.4 & 0.039 & 62.9 & 0.044 & 66.0 & 0.040 \\
\hline Mean & - & 0.040 & - & 0.041 & - & 0.041 \\
\hline
\end{tabular}

${ }^{1}$ Weight of concrete.

\subsection{Non-treated concrete}

The maximum levels of chloride penetration occurred in the case of non-treated concrete (NC) exposed to different de-icing chemicals (Table 6). The penetrated water-soluble chloride content at $15 \mathrm{~mm}$ depth was 0.164 , $0.159,0.055$ and $0.229 \%$ due to exposure to $\mathrm{NaCl}, \mathrm{Ge}-$ omelt $\mathrm{S} 30, \mathrm{CaCl}_{2}$, that is, and $\mathrm{MgCl}_{2}$, respectively. The chloride penetration at $15 \mathrm{~mm}$ depth was zero due to exposure to $\mathrm{H}_{2} \mathrm{O}$ (Table 6).

\subsection{Sealer treated concrete}

The penetrated water-soluble chloride content of the sealer treated concrete exposed to $\mathrm{H}_{2} \mathrm{O}$ was zero at 15 , 30 and $45 \mathrm{~mm}$ depths (Table 6). In the cases of exposures to $\mathrm{NaCl}$, Geomelt $\mathrm{S} 30, \mathrm{CaCl}_{2}$ and $\mathrm{MgCl}_{2}$ de-icing chemicals, the penetrated water-soluble chloride content at $15 \mathrm{~mm}$ depth was $0.079,0.019,0.008$ and $0.006 \%$, respectively. At 30 and $45 \mathrm{~mm}$ depths, the penetrated water-soluble chloride contents were zero for the aforementioned de-icing chemical exposures (Table 6). 
Table 5. Total water-soluble chloride content of concrete exposed to different chemicals

\begin{tabular}{|c|c|c|c|c|c|c|c|}
\hline \multirow{3}{*}{$\begin{array}{l}\text { Chemical } \\
\text { exposure }\end{array}$} & \multirow{3}{*}{$\begin{array}{l}\text { Type of } \\
\text { surface } \\
\text { treatment }\end{array}$} & \multicolumn{6}{|c|}{ Depth of sampling } \\
\hline & & \multicolumn{2}{|c|}{$15 \mathrm{~mm}$} & \multicolumn{2}{|c|}{$30 \mathrm{~mm}$} & \multicolumn{2}{|c|}{$45 \mathrm{~mm}$} \\
\hline & & $\begin{array}{l}\text { Potential } \\
(\mathrm{mV})\end{array}$ & $\begin{array}{c}\text { Chloride } \\
\left(\% \mathrm{C}^{1}\right)\end{array}$ & $\begin{array}{l}\text { Potential } \\
(\mathrm{mV})\end{array}$ & $\begin{array}{c}\text { Chloride } \\
(\% \mathrm{C})\end{array}$ & $\begin{array}{l}\text { Potential } \\
(\mathrm{mV})\end{array}$ & $\begin{array}{c}\text { Chloride } \\
\text { (\% C) }\end{array}$ \\
\hline \multirow{5}{*}{$\mathrm{H}_{2} \mathrm{O}$} & $\mathrm{NC}$ & 65.6 & 0.040 & 66.2 & 0.040 & 71.1 & 0.033 \\
\hline & SS1 & 78.1 & 0.025 & 76.3 & 0.027 & 64.6 & 0.041 \\
\hline & $\mathrm{AC} 1$ & 71.7 & 0.031 & 76.1 & 0.027 & 70.3 & 0.034 \\
\hline & $\mathrm{CC} 1$ & 64.8 & 0.041 & 65.3 & 0.041 & 65.5 & 0.040 \\
\hline & $\mathrm{CC} 2$ & 68.1 & 0.037 & 68.8 & 0.035 & 65.0 & 0.041 \\
\hline \multirow{5}{*}{$\mathrm{NaCl}$} & $\mathrm{NC}$ & 23.8 & 0.205 & 74.7 & 0.028 & 68.7 & 0.035 \\
\hline & SS1 & 37.4 & 0.120 & 64.6 & 0.041 & 65.1 & 0.041 \\
\hline & $\mathrm{AC} 1$ & 66.4 & 0.040 & 71.5 & 0.032 & 71.1 & 0.033 \\
\hline & $\mathrm{CC} 1$ & 51.9 & 0.068 & 69.4 & 0.035 & 65.6 & 0.040 \\
\hline & $\mathrm{CC} 2$ & 61.5 & 0.047 & 65.2 & 0.041 & 65.3 & 0.041 \\
\hline \multirow{5}{*}{ Geomelt S30 } & $\mathrm{NC}$ & 24.4 & 0.200 & 69.9 & 0.034 & 73.9 & 0.029 \\
\hline & $\mathrm{SS} 1$ & 55.7 & 0.060 & 64.9 & 0.041 & 70.4 & 0.033 \\
\hline & $\mathrm{AC} 1$ & 66.1 & 0.040 & 65.3 & 0.041 & 64.5 & 0.041 \\
\hline & $\mathrm{CC} 1$ & 56.1 & 0.058 & 65.4 & 0.041 & 70.2 & 0.034 \\
\hline & $\mathrm{CC} 2$ & 68.1 & 0.037 & 64.5 & 0.041 & 70.3 & 0.034 \\
\hline \multirow{5}{*}{$\mathrm{CaCl}_{2}$} & $\mathrm{NC}$ & 43.5 & 0.096 & 72.1 & 0.031 & 73.6 & 0.029 \\
\hline & SS1 & 60.4 & 0.049 & 65.0 & 0.041 & 64.8 & 0.041 \\
\hline & $\mathrm{AC} 1$ & 69.9 & 0.034 & 67.2 & 0.038 & 67.2 & 0.038 \\
\hline & $\mathrm{CC} 1$ & 49.9 & 0.074 & 64.6 & 0.041 & 66.8 & 0.038 \\
\hline & $\mathrm{CC} 2$ & 55.4 & 0.060 & 65.5 & 0.040 & 67.0 & 0.038 \\
\hline \multirow{5}{*}{$\mathrm{MgCl}_{2}$} & $\mathrm{NC}$ & 16.9 & 0.270 & 68.3 & 0.037 & 65.5 & 0.040 \\
\hline & SS1 & 61.5 & 0.047 & 64.9 & 0.041 & 71.3 & 0.032 \\
\hline & $\mathrm{AC} 1$ & 67.1 & 0.038 & 64.8 & 0.041 & 64.9 & 0.041 \\
\hline & $\mathrm{CC} 1$ & 50.3 & 0.074 & 65.9 & 0.040 & 65.7 & 0.040 \\
\hline & $\mathrm{CC} 2$ & 61.2 & 0.048 & 72.5 & 0.031 & 71.9 & 0.031 \\
\hline
\end{tabular}

${ }^{1}$ Weight of concrete

\subsection{Acrylic-based coating (AC1) treated concrete}

The penetrated water-soluble chloride content of the acrylic-based coating treated concrete was zero at 15 , 30 and $45 \mathrm{~mm}$ depths when exposed to $\mathrm{H}_{2} \mathrm{O}$ and $\mathrm{NaCl}$, Geomelt $\mathrm{S} 30, \mathrm{CaCl}_{2}$, and $\mathrm{MgCl}_{2}$ de-icing chemicals (Table 6).

\subsection{First cementitious coating (CC1) treated concrete}

The penetrated water-soluble chloride content of the $\mathrm{CC} 1$ cementitious coating treated concrete was zero at 15,30 and $45 \mathrm{~mm}$ depths when exposed to $\mathrm{H}_{2} \mathrm{O}$ (Table 6). When exposed to $\mathrm{NaCl}$, Geomelt $\mathrm{S} 30, \mathrm{CaCl}_{2}$ and $\mathrm{MgCl}_{2}$ de-icing chemicals, the penetrated water-soluble chloride content at $15 \mathrm{~mm}$ depth was $0.027,0.017,0.033$ and $0.033 \%$, respectively (Table 6 ). The penetrated chloride content at 30 and $45 \mathrm{~mm}$ depths was zero in the case of exposures to all de-icing chemicals (Table 6).

\subsection{Second cementitious coating (CC2) treated concrete}

The penetrated water-soluble chloride content of the $\mathrm{CC} 2$ cementitious coating treated concrete was zero at 15,30 and $45 \mathrm{~mm}$ depths in the case of $\mathrm{H}_{2} \mathrm{O}$ exposure (Table 6). The penetrated water-soluble chloride content at $15 \mathrm{~mm}$ depth was $0.006,0,0.019$ and $0.007 \%$, when exposed to $\mathrm{NaCl}$, Geomelt $\mathrm{S} 30, \mathrm{CaCl}_{2}$ and $\mathrm{MgCl}_{2}$ de-icing chemicals, respectively (Table 6). At 30 and $45 \mathrm{~mm}$ depths, the penetrated water-soluble chloride content was zero in the cases of exposures to all de-icing chemicals (Table 6).

\subsection{Effects of different de-icing chemicals}

The penetrated water-soluble chloride content of the non-treated concrete ranged from 0.055 to $0.229 \%$ by weight of concrete in the cases of exposures to different de-icing chemicals (Table 6). According to CSA A23.1-09/A23.2-09 (2009), the maximum allowable water-soluble chloride content in new concrete exposed to a moist environment or chlorides or both is $0.15 \%$ 
Table 6. Penetrated water-soluble chloride content of concrete exposed to different chemicals

\begin{tabular}{|c|c|c|c|c|c|c|c|c|}
\hline \multirow{3}{*}{$\begin{array}{l}\text { Chemical } \\
\text { exposure }\end{array}$} & \multirow{3}{*}{$\begin{array}{l}\text { Avg. baseline } \\
\text { chlorides } \\
\left(\% \mathrm{C}^{1}\right)\end{array}$} & \multirow{3}{*}{$\begin{array}{l}\text { Type of surface } \\
\text { treatment }\end{array}$} & \multicolumn{3}{|c|}{$\begin{array}{l}\text { Total water-soluble chlorides } \\
\qquad(\% \mathrm{C})\end{array}$} & \multicolumn{3}{|c|}{$\begin{array}{c}\text { Penetrated water-soluble } \\
\text { chlorides }{ }^{2} \\
(\% \mathrm{C})\end{array}$} \\
\hline & & & \multicolumn{3}{|c|}{ Penetration depth (mm) } & \multicolumn{3}{|c|}{ Penetration depth $(\mathrm{mm})$} \\
\hline & & & 15 & 30 & 45 & 15 & 30 & 45 \\
\hline \multirow{5}{*}{$\mathrm{NC}$} & \multirow{5}{*}{0.041} & $\mathrm{H}_{2} \mathrm{O}$ & 0.040 & 0.040 & 0.033 & 0 & 0 & 0 \\
\hline & & $\mathrm{NaCl}$ & 0.205 & 0.028 & 0.035 & 0.164 & 0 & 0 \\
\hline & & Geomelt S30 & 0.200 & 0.034 & 0.029 & 0.159 & 0 & 0 \\
\hline & & $\mathrm{CaCl}_{2}$ & 0.096 & 0.031 & 0.029 & 0.055 & 0 & 0 \\
\hline & & $\mathrm{MgCl}_{2}$ & 0.270 & 0.037 & 0.040 & 0.229 & 0 & 0 \\
\hline \multirow{5}{*}{ SS1 } & \multirow{5}{*}{0.041} & $\mathrm{H}_{2} \mathrm{O}$ & 0.025 & 0.027 & 0.041 & 0 & 0 & 0 \\
\hline & & $\mathrm{NaCl}$ & 0.120 & 0.041 & 0.041 & 0.079 & 0 & 0 \\
\hline & & Geomelt S30 & 0.060 & 0.041 & 0.033 & 0.019 & 0 & 0 \\
\hline & & $\mathrm{CaCl}_{2}$ & 0.049 & 0.041 & 0.041 & 0.008 & 0 & 0 \\
\hline & & $\mathrm{MgCl}_{2}$ & 0.047 & 0.041 & 0.032 & 0.006 & 0 & 0 \\
\hline \multirow{5}{*}{$\mathrm{AC} 1$} & \multirow{5}{*}{0.041} & $\mathrm{H}_{2} \mathrm{O}$ & 0.031 & 0.027 & 0.034 & 0 & 0 & 0 \\
\hline & & $\mathrm{NaCl}$ & 0.040 & 0.032 & 0.033 & 0 & 0 & 0 \\
\hline & & Geomelt S30 & 0.040 & 0.041 & 0.041 & 0 & 0 & 0 \\
\hline & & $\mathrm{CaCl}_{2}$ & 0.034 & 0.038 & 0.038 & 0 & 0 & 0 \\
\hline & & $\mathrm{MgCl}_{2}$ & 0.038 & 0.041 & 0.041 & 0 & 0 & 0 \\
\hline \multirow{5}{*}{$\mathrm{CC} 1$} & \multirow{5}{*}{0.041} & $\mathrm{H}_{2} \mathrm{O}$ & 0.041 & 0.041 & 0.040 & 0 & 0 & 0 \\
\hline & & $\mathrm{NaCl}$ & 0.068 & 0.035 & 0.040 & 0.027 & 0 & 0 \\
\hline & & Geomelt S30 & 0.058 & 0.041 & 0.034 & 0.017 & 0 & 0 \\
\hline & & $\mathrm{CaCl}_{2}$ & 0.074 & 0.041 & 0.038 & 0.033 & 0 & 0 \\
\hline & & $\mathrm{MgCl}_{2}$ & 0.074 & 0.040 & 0.040 & 0.033 & 0 & 0 \\
\hline \multirow{5}{*}{$\mathrm{CC} 2$} & \multirow{5}{*}{0.041} & $\mathrm{H}_{2} \mathrm{O}$ & 0.037 & 0.035 & 0.041 & 0 & 0 & 0 \\
\hline & & $\mathrm{NaCl}$ & 0.047 & 0.041 & 0.041 & 0.006 & 0 & 0 \\
\hline & & Geomelt S30 & 0.037 & 0.041 & 0.034 & 0 & 0 & 0 \\
\hline & & $\mathrm{CaCl}_{2}$ & 0.060 & 0.040 & 0.038 & 0.019 & 0 & 0 \\
\hline & & $\mathrm{MgCl}_{2}$ & 0.048 & 0.031 & 0.031 & 0.007 & 0 & 0 \\
\hline
\end{tabular}

${ }^{1}$ Weight of concrete;

${ }^{2}$ Penetrated water-soluble chloride $=$ Total chlorides - Baseline chlorides, taken as zero if the number is negative.

by weight of cementing materials. For ordinary concrete produced with a cement content varying in the range of $300-400 \mathrm{~kg} / \mathrm{m}^{3}$, this is equivalent to a chloride limit of $0.019-0.025 \%$ by weight of concrete $(0.45-0.60 \mathrm{~kg}$ per $1 \mathrm{~m}^{3}$ of concrete). Hence, the penetrated water-soluble chloride content of the non-treated concrete was significantly more than the maximum allowable chloride limit. This result suggests that the susceptibility of non-treated concrete to reinforcement corrosion is relatively high. Geomelt S30 had a significantly reduced penetration of chlorides as compared to $\mathrm{NaCl}$. This is because Geomelt S30 has a lower amount of NaCl-brine in its solution formulation (Table 2). Exposure to $\mathrm{CaCl}_{2}$ led to the lowest penetrated water-soluble chlorides $(0.055 \%)$ in the non-treated concrete. Although this chloride content exceeded the maximum allowable limit of 0.019$0.025 \%$, it was significantly lower than the penetrated water-soluble chlorides caused by $\mathrm{NaCl}$ and $\mathrm{MgCl}_{2}$ deicing chemicals. This is because the diffusion of $\mathrm{CaCl}_{2}$ into concrete is slower than that of $\mathrm{NaCl}$ (Hooton, Julio-Betancourt 2005; Mussato et al. 2004). In addition, calcium oxy-chloride forms in the presence of $\mathrm{CaCl}_{2}$. The formation of such product decreases the amount of water-soluble (free) chlorides in concrete. As a result, the penetrated water-soluble chlorides were lower for the concrete exposed to $\mathrm{CaCl}_{2}$ de-icing chemical. However, the formation of expansive oxy-chloride results in reduced compressive strength and increased permeability due to cracking in concrete (Julio-Betancourt 2009; Sutter et al. 2008). These adverse physical effects accelerate concrete deterioration, and thus can supersede the positive effect of reduced water-soluble chloride content in the case $\mathrm{CaCl}_{2}$ exposure.

Exposure to $\mathrm{MgCl}_{2}$ caused the maximum chloride penetration $(0.229 \%)$ into non-treated concrete (Table 6). It was substantially greater than the penetrated watersoluble chlorides caused by $\mathrm{NaCl}$ exposure. This finding suggests that $\mathrm{MgCl}_{2}$ could be more detrimental to cause 
corrosion of steel reinforcement in reinforced concrete. $\mathrm{MgCl}_{2}$ diffuses into concrete much slower than $\mathrm{NaCl}$ and $\mathrm{CaCl}_{2}$ (Hooton, Julio-Betancourt 2005; Mussato et al. 2004). Yet the penetrated water-soluble chloride content was significantly higher in the case of exposure to $\mathrm{MgCl}_{2}$ versus $\mathrm{NaCl}$ or $\mathrm{CaCl}_{2}$. Xi and Xie (2002) reported that $\mathrm{MgCl}_{2}$ can be more corrosive than $\mathrm{NaCl}$ under humid conditions. When exposed to drying, $\mathrm{MgCl}_{2}$ can adhere and crystallize more easily onto a solid (aggregate, steel reinforcement, etc.) surface because of its higher viscosity; this salt can also easily convert back to a solution during wetting due to its greater hydrophilic nature (Kozikowski et al. 2007). Consequently, the penetrated water-soluble chlorides can be higher in the case of exposure to $\mathrm{MgCl}_{2}$ de-icing chemical.

The effect of de-icing chemicals on surface-treated concrete with respect to penetrated water-soluble chlorides significantly varied depending on the type of surface treatment (Table 6). None of the de-icing chemicals caused any chloride penetration into the acrylic-based coating treated concrete. $\mathrm{NaCl}$ resulted in the highest penetrated watersoluble chlorides (substantially higher than the maximum allowable limit of $0.019-0.025 \%$ ) in the case of sealer treated concrete. This suggests that the water repelling performance of the sealer was less effective when exposed to $\mathrm{NaCl}$ de-icing solution. This is because $\mathrm{NaCl}$ de-icing solution had a relatively low amount of net water in its formulation (Table 2). In the cases of the two cementitious coating treated concretes, $\mathrm{CaCl}_{2}$ and $\mathrm{MgCl}_{2}$ caused more chloride penetration than $\mathrm{NaCl}$ and Geomelt S30 (Table 6). However, $\mathrm{CaCl}_{2}$ and $\mathrm{MgCl}_{2}$ produced the maximum chloride penetration $(0.033 \%)$ for the $\mathrm{CC} 1$ coating treated concrete. This is because these two de-icing chemicals formed significant pin holes in the $\mathrm{CC} 1$ coating due to dissolution (Soudki et al. 2011). Due to the similar reason, exposure to $\mathrm{CaCl}_{2}$ also caused the maximum chloride penetration $(0.019 \%)$ into the CC2 coating treated concrete. However, all de-icing chemicals produced a higher chloride penetration for $\mathrm{CC} 1$ coating than $\mathrm{CC} 2$ coating. In the cases of both $\mathrm{CC} 1$ and $\mathrm{CC} 2$ coatings, Geomelt $\mathrm{S} 30$ produced

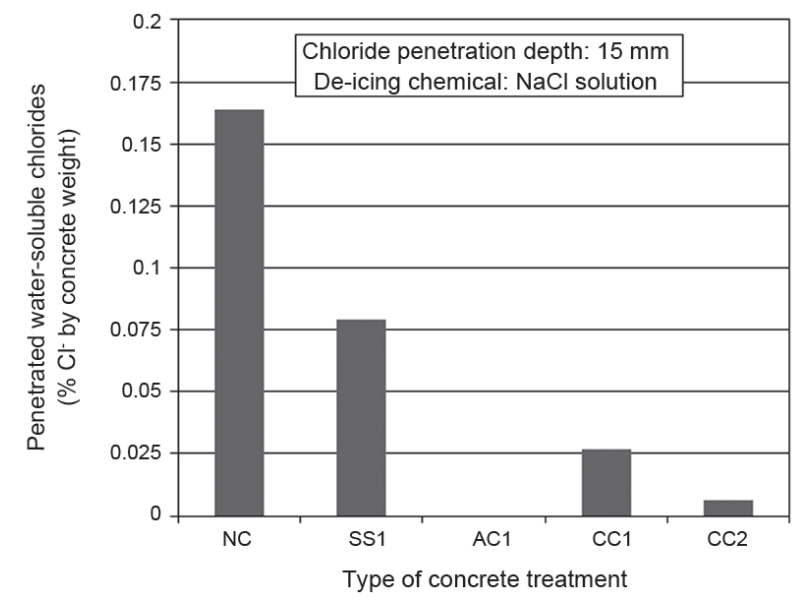

Fig. 4. Chloride ion penetration of non-treated and treated concretes exposed to $\mathrm{NaCl}$ solution less chloride penetration than $\mathrm{NaCl}$. This is due to a lower amount of $\mathrm{NaCl}$ in its formulation with $70 \%$ brine and $30 \%$ Geomelt 55 concentrate (Table 2).

\subsection{Effects of different sealer and coating products}

The sealer and coating products significantly reduced the penetration of chlorides into concrete, as compared with the non-treated concrete (Table 6, Fig. 4). The acrylicbased coating $(\mathrm{AC} 1)$ had the best performance in resisting the penetration of chloride ions into concrete. The sealer (SS1) had the worst performance in resisting the penetration of chloride ions into concrete when exposed to $\mathrm{NaCl}$ (Fig. 4). However, the chloride penetration for the sealer (SS1) was lower than that of the two cementitious coatings $\left(\mathrm{CC} 1\right.$ and $\mathrm{CC} 2$ ) when exposed to $\mathrm{CaCl}_{2}$ and $\mathrm{MgCl}_{2}$ de-icing chemicals (Table 6). Sealer SS1 is a penetrating sealer product that produces hydrophobic reactions by lining capillary pores. As a result, this sealer can repel water or chloride-laden water. The water repelling performance was more effective in the cases of $\mathrm{CaCl}_{2}$ and $\mathrm{MgCl}_{2}$ de-icing solutions, since they have a greater amount of net water in their formulations. It is evident from Table 2 that $\mathrm{CaCl}_{2}$ and $\mathrm{MgCl}_{2}$ contributed $15 \%$ and $53 \%$ water to their respective solution. Hence, more chloride-laden water was repelled in these two deicing solutions, resulting in less free chlorides.

The second cementitious coating (CC2) performed better than the first cementitious coating $(\mathrm{CC} 1)$ in resisting the chloride ion penetration into concrete. Among the three coating products, the highest level of penetrated water-soluble chlorides at $15 \mathrm{~mm}$ depth was observed for the coating CC1 (Table 6, Fig. 4). This is due to a greater number of pin holes that occurred in the $\mathrm{CC} 1$ coating during exposure to de-icing chemicals. The penetrated watersoluble chloride content of $\mathrm{CC} 1$ coating treated concrete was greater than the maximum allowable chloride limit in the cases of exposures to $\mathrm{NaCl}, \mathrm{CaCl}_{2}$ and $\mathrm{MgCl}_{2}$ deicing chemicals.

\section{Conclusions}

This study was carried out to determine the chloride ion penetration resistance of four selected sealer/coating products when exposed to five different chemicals (water and de-icing chemicals). Based on the findings of the present study, the following conclusions can be drawn:

1) The maximum levels of chloride ion penetration for all chemical exposures occurred at a $15 \mathrm{~mm}$ depth from the concrete surface. No chloride penetration occurred at 30 and $45 \mathrm{~mm}$ depths from the concrete surface.

2) The lowest levels of chloride ion penetration for both non-treated and treated concretes occurred when exposed to $\mathrm{H}_{2} \mathrm{O}$. In contrast, the highest degrees of chloride ion penetration were observed when exposed to different de-icing chemicals.

3) The highest chloride ion penetration occurred for the non-treated concrete. $\mathrm{MgCl}_{2}$ exhibited greater chloride ion penetration due to its greater hydrophilic 
nature than other de-icing salts. In contrast, $\mathrm{CaCl}_{2}$ exhibited lower chloride ion penetration due to the involvement of free chlorides in the formation of calcium oxy-chloride.

4) The chloride ion penetration resistance of both treated and non-treated concretes was better when exposed to Geomelt $\mathrm{S} 30$ than when exposed to $\mathrm{NaCl}$; this is due to the reduced amount of $\mathrm{NaCl}$ in Geomelt S30 including brine and Geomelt 55 concentrate.

5) Sealer SS1 exhibited good performance in the cases of $\mathrm{CaCl}_{2}$ and $\mathrm{MgCl}_{2}$ exposures due to its better water-repellent characteristic in the presence of a higher quantity of water.

6) The performance of the selected sealer and coating products with respect to chloride ion penetration resistance under different environmental exposures with de-icing chemicals can be expressed in the following order from best to worst ranking: $\mathrm{AC} 1>$ $\mathrm{CC} 2>\mathrm{CC} 1>\mathrm{SS} 1$.

\section{Acknowledgements}

The authors are grateful to the Region of Waterloo for funding this research study, and for taking the leading role in supplying the sealer/coating products and the de-icing chemical, Geomelt S30, used in the study. The authors also express gratitude to Innovative Surface Solutions for supplying $\mathrm{NaCl}, \mathrm{CaCl}_{2}$ and $\mathrm{MgCl}_{2}$ de-icing salts required for the research study.

\section{References}

AASHTO T 259-02. Standard specifications for transportation materials and methods of sampling and testing. Part II. American Association of State Highway and Transportation Officials (AASHTO). Washington D.C., USA, 2006.

Al-Dulaijan, S. U.; Maslehuddin, M.; Al-Zahrani, M. M.; AlJuraifani, E. A.; Al-Idi, S. H.; Al-Mehthel, M. 2000. Performance evaluation of cement-based surface coatings, in Proc. of the ACI Fourth International Conference on Repair, Rehabilitation, and Maintenance of Concrete Structures, and Innovations in Design and Construction (ACI SP-193), September 2000, American Concrete Institute, Detroit, Michigan, USA, 321-335.

Almusallam, A. A.; Khan, F. M.; Dulaijan, S. U.; Al-Amoudi, O. S. B. 2003. Effectiveness of surface coatings in improving concrete durability, Cement and Concrete Composites 25(4-5): 473-481.

http://dx.doi.org/10.1016/S0958-9465(02)00087-2

ASTM C 1543-10a. Standard test method for determining the penetration of chloride ion into concrete by ponding. Annual Book of ASTM Standards, Vol. 04.02. American Society for Testing and Materials. Philadelphia, USA, 2010.

Bouteille, S.; Chong, T. F.; Dierkens, M.; Dangla, P.; Moral, N.; Boulanger, S. 2010. Penetration of chlorides in hardened concrete during frost salt scaling cycles, in ICEM 14 $14^{\text {th }}$ International Conference on Experimental Mechanics, Poitiers, EPJ Web of Conferences 6: 1-8. http://dx.doi.org/10.1051/epjconf/20100622017

CSA A23.1-09/A23.2-09. Concrete materials and methods of concrete construction/test methods and standard practices for concrete. Canadian Standards Association. Mississauga, Ontario, Canada, 2009.
Dhir, R. K.; Jones, M. R.; Ahmed, H. E. H. 1990. Determination of total and soluble chlorides in concrete, Cement and Concrete Research 20(4): 579-590. http://dx.doi.org/10.1016/0008-8846(90)90100-C

Hooton, R. D.; Julio-Betancourt, G. A. 2005. Investigations of the effects of various deicing chemicals, curing methods, and concrete placement on salt scaling resistance of concrete surface. Final Report to Ready Mixed Concrete Association of Ontario, University of Toronto, Ontario, Canada.

Ibrahim, M.; Al-Gahtani, A. S.; Maslehuddin, M.; Dakhil, F. H. 1999. Use of surface treatment materials to improve concrete durability, Journal of Materials in Civil Engineering ASCE 11(1): 36-40.

http://dx.doi.org/10.1061/(ASCE)0899-1561(1999)11:1(36)

ICRI. 1997. Selecting and specifying concrete surface preparation for sealers, coatings, and polymer overlays. Technical Guideline No. 03732, Virginia, USA: International Concrete Repair Institute (ICRI).

Julio-Betancourt, G. A. 2009. Effect of de-icer and anti-icer chemicals on the durability, microstructure, and properties of cement-based materials. PhD Dissertation. University of Toronto, Ontario, Canada.

Kamaitis, Z. 2007a. Structural design of polymer protective coatings for reinforced concrete structures. Part I: theoretical considerations, Journal of Civil Engineering and Management 13(1): 11-17. http://dx.doi.org/10.1080/13923730.2007.9636414

Kamaitis, Z. 2007b. Structural design of polymer protective coatings for reinforced concrete structures. Part II: experimental verification, Journal of Civil Engineering and Management 13(1): 19-26. http://dx.doi.org/10.1080/13923730.2007.9636415

Kamaitis, Z. 2008. Modelling of corrosion protection for reinforced concrete structures with surface coatings, Journal of Civil Engineering and Management 14(4): 241-249. http://dx.doi.org/10.3846/1392-3730.2008.14.23

Kozikowski, R. L.; Taylor, P. C.; Pyc, W. A. 2007. Evaluation of potential concrete deterioration related to magnesium chloride $\left(\mathrm{MgCl}_{2}\right)$ deicing salts, PCA R\&D Serial No. 2770. Portland Cement Association, Skokie, Illinois, USA.

Melchers, R. E.; Li, C. Q. 2009. Reinforcement corrosion initiation and activation times in concrete structures exposed to severe marine environments, Cement and Concrete Research 39(11): 1068-1076. http://dx.doi.org/10.1016/j.cemconres.2009.07.003

Moon, H. Y.; Shin, D. G.; Choi, D. S. 2007. Evaluation of the durability of mortar and concrete applied with inorganic coating material and surface treatment system, Construction and Building Materials 21(2): 362-369. http://dx.doi.org/10.1016/j.conbuildmat.2005.08.012

Mussato, B. T.; Gepraegs, O. K.; Farnden, G. 2004. Relative effects of sodium chloride and magnesium chloride on reinforced concrete, Transportation Research Record 1866: 59-66. http://dx.doi.org/10.3141/1866-08

Oshiro, T.; Tanigawa, S. 1988. Effect of surface coatings on the durability of concrete exposed to marine environment, in Proc. of the Second International Conference on Concrete in Marine Environment, 1988, New Brunswick, Canada, 179-198.

Palle, S.; Hopwood II, T. 2006. Coatings, sealants and fillers to address bridge concrete deterioration and aesthetics phase 1. Research Report No. KTC06-36/SPR 291-04-1F. Kentucky Transportation Center, College of Engineering, University of Kentucky, Lexington, Kentucky, USA.

Park, S.-S.; Kwon, S.-J.; Jung, S. H. 2012. Analysis technique for chloride penetration in cracked concrete using equivalent diffusion and permeation, Construction and Building Materials 29: 183-192. 
Pruckner, F.; Gjørv, O. E. 2004. Effect of $\mathrm{CaCl}_{2}$ and $\mathrm{NaCl}$ additions on concrete corrosivity, Cement and Concrete Research 34(7): 1209-1217. http://dx.doi.org/10.1016/j.cemconres.2003.12.015

RCTW. 2002. Instruction and maintenance manual. Illinois: German Instruments Inc. 16 p.

Safiuddin, Md.; Soudki, K. A. 2011. Sealer and coating systems for the protection of concrete bridge structures, International Journal of the Physical Sciences 6(37): 8188-8199. http://dx.doi.org/10.5897/IJPSX11.005

Saremi, M.; Mahallati, E. 2002. A study on chloride-induced depassivation of mild steel in simulated concrete pore solution, Cement and Concrete Research 32(12): 1915-1921. http://dx.doi.org/10.1016/S0008-8846(02)00895-5

Soudki, K. A.; Jeffs, P.; Safiuddin, Md. 2011. Concrete coating systems on region of Waterloo bridges. Final Research Report. Department of Civil and Environmental Engineering, University of Waterloo, Waterloo, Ontario, Canada.

Sutter, L. L.; Peterson, K.; Julio-Betancourt, G. A.; Hooton, R. D.; Van Dam, T. J.; Smith, K. 2008. The deleterious chemical effects of concentrated deicing solutions on Portland cement concrete - implementation guide. Research Report No. SD2002-01-G. Michigan Tech Transportation Institute, Houghton, Michigan, USA.

TRB. 1991. Highway de-icing: comparing salt and calcium magnesium acetate. Special Report 235. Transportation Research Board (TRB), National Research Council, Washington DC, USA.

TRB. 2007. Guidelines for the selection of snow and ice control materials to mitigate environmental impacts. NCHRP Report 577. Transportation Research Board (TRB), National Research Council, Washington DC, USA.

Wenzlick, J. D. 2007. Bridge deck concrete sealers. Final Research Report RI 04-051. Missouri Department of Transportation, Jefferson City, Missouri, USA.

Xi, Y.; Xie, Z. 2002. Corrosion effects of magnesium chloride and sodium chloride on automobile components. Research Report No. CDOT-DTD-R-2002-4. Colorado Department of Transportation, Denver, Colorado, USA.

Yoon, I. 2012. Chloride penetration through cracks in high-performance concrete and surface treatment system for crack healing, Advances in Materials Science and Engineering 2012: 1-8.

Khaled A. SOUDKI. Professor and the Canada Research Chair (Innovative Structural Rehabilitation) in the Department of Civil and Environmental Engineering at the University of Waterloo, Ontario, Canada. He has a P.Eng. Licence from Professional Engineers Ontario. He is a Member of American Concrete Institute Committees 440 (FRP Reinforcement), 222 (Corrosion of Metals) and 546 (Repair). His research interests include corrosion, durability performance of advanced materials, structural health monitoring, and rehabilitation of concrete structures using FRP composites.

Md. SAFIUDDIN. Research Associate in the Department of Civil and Environmental Engineering at the University of Waterloo, Ontario, Canada. He is a P.Eng. Licence holder of Professional Engineers Ontario. He is a Fellow of the Institution of Engineers, Bangladesh and a Member of Bangladesh Environmental Network. His research interests include building and pavement materials, sustainable engineering and architectural materials, and repair and rehabilitation of concrete structures.

Paul JEFFS. President of PJ Materials Consultants Limited. He has a career spanning over 40 years within the construction industry around the world, including the United Kingdom, the Middle East, The Far East, South East Asia and North America. He provides professional consulting services for the construction and restoration of concrete and masonry structures, and provides professional development training across Canada. He has served on Canadian Standards Association Technical Committees and has been a Guest Lecturer at many Canadian universities.

Gary MACDONALD. Head of Transportation Expansion/Rehabilitation Programs at the Region of Waterloo, Ontario, Canada. He is a registered Professional Engineer (P.Eng.) in the province of Ontario, Canada.

Marcos KROKER. Senior Project Manager in the Design and Construction Division of the Region of Waterloo, Ontario, Canada. $\mathrm{He}$ is a registered Professional Engineer (P.Eng.) in the province of Ontario, Canada. 